\title{
Making the Best of a Bad Situation: Early Chronic Nosocomial $\mathrm{HCV}$ infection
}

\author{
Carmi Santos • Steven K. Herrine
}

Published online: 18 May 2010

(C) Springer Science+Business Media, LLC 2010

As the hepatitis $\mathrm{C}$ epidemic enters its third decade, several trends have become evident: incidence has decreased, prevalence is leveling off, therapy is becoming more individualized, and developments in pharmacotherapy and pharmacogenomics promise to improve treatment outcomes. It is frustrating in this setting that although intravenous drug use continues to be the primary mode of transmission of hepatitis $\mathrm{C}$ virus (HCV) in the United States and Europe, nosocomial outbreaks of HCV infection continue to be reported [1-3]. Such outbreaks are not new, having been extensively reported and analyzed in the setting of hemodialysis and poor infection control when using multidose saline vials, heparin solutions, and pain remediation treatments [4-7].

Such outbreaks, while preventable and disconcerting, offer the opportunity to study the natural history of acute hepatitis $\mathrm{C}$. As all chronic cases of HCV infection were at one time acute, we can imply the modes of transmission, spontaneous clearance rates, natural history and treatment responsiveness, but lack the ability afforded by analysis of acute cases to determine such information prospectively. Although most cases of acute $\mathrm{HCV}$ infection are thought to be asymptomatic, studies of acute hepatitis $\mathrm{C}$ have generally enrolled symptomatic patients. In this cohort, spontaneous clearance seems higher than in case series of chronic

\section{Santos}

Department of Internal Medicine, Thomas Jefferson University, 833 Chestnut Street, Suite 220, Philadelphia, PA 19107, USA e-mail: carmi.santos@jeffersonhospital.org

\section{S. K. Herrine $(\square)$}

Division of Gastroenterology and Hepatology, Thomas Jefferson University, 132 S. 10th Street, Suite 450, Philadelphia, PA 19107, USA

e-mail: steven.herrine@jefferson.edu hepatitis $C$ [8]. Generalization of the natural history of $\mathrm{HCV}$ infection from both acute cohorts is problematic, as variations of mode of transmission, age at transmission, gender, race, and presence of medical comorbidities affect outcome and treatment response [9].

Management of acute HCV infection remains unsettled, but guidelines based on available studies do exist. Initiation of treatment is recommended in order to prevent treatment of patients with high likelihood of spontaneous viral clearance. Reports of such spontaneous resolution of infection vary from 0 to $80 \%$ with a mean of $26 \%$, depending on both viral and host factors [8, 10-13]. Conversely, too lengthy a delay in therapy adversely affects treatment response. The optimal time of initiation of treatment remains a topic of debate, but most studies recommend waiting no longer than 8-16 weeks from transmission [14, 15].

Pharmacologic therapy for acute HCV infection has not been standardized regarding medication or duration, but has been demonstrated to be cost-effective in two metaanalyses [14, 16]. Interferon monotherapy, both unmodified and PEGylated, has been the mainstay of clinical trials and has been rewarded with very high rates of sustained virologic response (SVR). As with chronic HCV infections, patients with genotype 2 and 3 have a higher SVR than those with genotype 1 , but response rates in excess of $90 \%$ are commonly reported. Duration of therapy may be as short as 12 weeks in those patients demonstrating clearance of virus at 4 weeks of therapy (early virologic response, EVR) and as long as 48 weeks in those with genotype 1 and 4 disease and no EVR. The addition of ribavirin has not demonstrably increased SVR rates in the treatment of acute hepatitis C [17-20].

In this issue of Digestive Diseases and Sciences, Fazili and co-investigators make a significant contribution to our 
understanding of acute nosocomial $\mathrm{HCV}$ infection as they describe the natural history of an outbreak and treatment in the "early chronic" stage of the disease, defined as within 2 years of exposure [21]. This retrospective study serves two distinct purposes: first, it follows the outcome of a cohort of patients who were infected with $\mathrm{HCV}$ at a pain management clinic in Oklahoma. Secondly, the paper reports the results of pharmacologic treatment in a realworld setting-various physicians, using various drugs, using various endpoints. Although not optimal from a study design standpoint, the data presented offers an intriguing and important glimpse into how we might actually encounter such patients.

Of the 908 patients treated at the pain management facility between April 12, 1999, and July 22, 2002, 71 $(8.9 \%)$ met the criteria of having been nosocomially infected with $\mathrm{HCV}$ at the clinic, 50 of whom were included in the retrospective review. Unlike most studies of acute hepatitis $\mathrm{C}$ that recruit patients based on symptoms, only $12 \%$ of this cohort presented with acute symptomatic HCV infection. Another 21 patients later reported jaundice at their initial interview, suggesting recall bias. Thirty-one patients were treated with peginterferon and ribavirin, usually within several months after exposure. Although initiation of treatment ranged from 140 to 1,099 days after exposure, $98 \%$ of these patients were initiated with treatment 140-660 days after exposure.

The results were consistent with previous studies of acute hepatitis C. Eleven of 50 study patients (22\%) spontaneously cleared the virus, a result in the range that has been consistently reported. Those that cleared were generally younger than those who did not spontaneously clear the virus. SVR was observed in $65 \%$ of all patients treated with the usual genotype effect-SVR was $100 \%$ for genotype 3a, $64 \%$ for genotype 1a, and 33\% for genotype 2b. Twenty-one (91\%) of the 22 patients who completed therapy achieved SVR. In this rather late-treated and diverse population, SVR did not differ depending on length of time from exposure to treatment. The overall SVR, more in the range of that seen in treatment of chronic hepatitis $\mathrm{C}$, suggests a decrease in response beyond 5 months from exposure as well as the difference in SVR according to genotype. The lower SVR compared to results found in studies of acute HCV infection may also reflect the relatively high asymptomatic rate of the cohort.

While this report offers novel insight into the history and outcome of patients with "early chronic" infections, the study is limited by its retrospective design. The ideal study of this outbreak would have followed previously uninfected patients prospectively from transmission, begun therapy within 3 months, and used the same treatment regimen. However, because this report reflects the compromises of actual practice, the outbreak was reported months after the exposure, an earlier diagnosis and treatment was not possible, and only $18 \%$ of the cohort had been tested for HCV prior to receiving pain treatments. The patients were treated at various clinics, so treatments were not uniform. Differences in outcome depending on choice of interferon and duration of treatment were not captured. Furthermore, the homogeneity of the study population (all of whom were Caucasian) may well have affected treatment results, given the lower success of $\mathrm{HCV}$ antiviral therapy in AfricanAmericans [22].

These design problems now stated, the current report offers insights into a unique timeframe and presentation that has not been reviewed in available literature. The outcome of patients infected by way of a common source eliminates potential differences due to mode of transmission, similar to the important anti-D immunoglobulin infected cohort [23]. Although past medical history of the patients was not provided, this patient group did not share a chronic disease that may affect the outcome in other outbreaks, such as in cases of transmission through hemodialysis [24]. Most importantly, the study evaluates a group of asymptomatic $\mathrm{HCV}$ patients who are in the early months of a chronic infection. Because the data from the pain remediation clinics enabled the investigators to monitor patients' outcomes from the most likely day of transmission, the study describes the period now coined "early chronic." Although pharmacologic treatment was initiated just beyond the recommended timeframe for treatment initiation of acute hepatitis $C$, the resulting SVR was instead similar to results seen in the treatment of chronic $\mathrm{HCV}$ infection. This similarity suggests that once beyond the optimal initiation time, outcomes suffer and quickly reach the asymptote of success rates of treatment of chronic $\mathrm{HCV}$ infection.

Perhaps the most significant contribution of this study is its extraction of substantial data from a disturbing situation. The data presented here will not be available from randomized trials. Randomization of asymptomatic acutely infected individuals with $\mathrm{HCV}$ to treatment delays such as those seen in this report would be difficult to justify. Although the unfortunate occurrence of nosocomial infections cannot be mitigated by the generation of data about the history and management of $\mathrm{HCV}$ infections, the knowledge offered by this report deserves to see the light of day.

\section{References}

1. Morin T, Pariente A, Lahmek P, et al. Acute hepatitis C: Analysis of a 126-case prospective, multicenter cohort. Eur J Gastroenterol Hepatol. 2010;22:157-166. 
2. Ross RS, Viazov S, Khudyakov YE, et al. Transmission of hepatitis $\mathrm{C}$ virus in an orthopedic hospital ward. J Med Virol. 2009;81:249-257.

3. Pañella H, Rius C, Caylà JA. Transmission of hepatitis C virus during computed tomography scanning with contrast. Emerg Infect Dis. 2008;14:333-336.

4. Krause G, Trepka MJ, Whisenhunt RS, et al. Nosocomial transmission of hepatitis $\mathrm{C}$ virus associated with the use of multidose saline vials. Infect Control Hosp Epidemiol. 2003;24:122-127.

5. Bronowicki JP, Venard V, Botté C, et al. Patient-to-patient transmission of hepatitis $\mathrm{C}$ virus during colonoscopy. $N$ Engl $J$ Med. 1997;337:237-240.

6. Savey A, Simon F, Izopet J, Lepoutre A, Fabry J, Desenclos JC. A large nosocomial outbreak of hepatitis $\mathrm{C}$ virus infections at a hemodialysis center. Infect Control Hosp Epidemiol. 2005;26: 752-760.

7. Comstock RD, Mallonee S, Fox JL, et al. A large nosocomial outbreak of hepatitis $\mathrm{C}$ and hepatitis $\mathrm{B}$ among patients receiving pain remediation treatments. Infect Control Hosp Epidemiol. 2004;25:576-583.

8. Gerlach JT, Diepolder HM, Zachoval R, et al. Acute hepatitis C: High rate of both spontaneous and treatment-induced viral clearance. Gastroenterology. 2003;125:80-88.

9. Maheshwari A, Ray S, Thuluvath PJ. Acute hepatitis C. Lancet. 2008;372:321-332.

10. Micallef JM, Kaldor JM, Dore GJ. Spontaneous viral clearance following acute hepatitis $\mathrm{C}$ infection: a systematic review of longitudinal studies. J Viral Hepat. 2006;13:34-41.

11. Wang CC, Krantz E, Klarquist J, et al. Acute hepatitis $\mathrm{C}$ in a contemporary US cohort: modes of acquisition and factors influencing viral clearance. J Infect Dis. 2007;196:1474-1482.

12. Kamal SM, Fouly AE, Kamel RR, et al. Peginterferon alfa- $2 b$ therapy in acute hepatitis $\mathrm{C}$ : impact of onset of therapy on sustained virologic response. Gastroenterology. 2006;130:632-638.

13. Hofer H, Watkins-Riedel T, Janata O, et al. Spontaneous viral clearance in patients with acute hepatitis $\mathrm{C}$ can be predicted by repeated measurements of serum viral load. Hepatology. 2003;37:60-64.
14. Alberti A, Boccato S, Vario A, Benvegnù L. Therapy of acute hepatitis C. Hepatology. 2002;36:S195-S200.

15. Maheshwari A, Thuluvath PJ. Management of acute hepatitis C. Clin Liver Dis. 2010;14:169-176.

16. Licata A, Di Bona D, Schepis F, Shahied L, Craxí A, Cammà C. When and how to treat acute hepatitis C? J Hepatol. 2003;39:1056-1062.

17. Corey KE, Ross AS, Wurcel A, et al. Outcomes and treatment of acute hepatitis C virus infection in a United States population. Clin Gastroenterol Hepatol. 2003;4:1278-1282.

18. Santantonio T, Fasano M, Sinisi E, et al. Efficacy of a 24-week course of PEG-interferon alpha-2b monotherapy in patients with acute hepatitis $\mathrm{C}$ after failure of spontaneous clearance. J Hepatol. 2005;42:329-333.

19. Wiegand J, Buggisch P, Boecher W, et al. Early monotherapy with PEGylated interferon alpha-2b for acute hepatitis $\mathrm{C}$ infection: the HEP-NET acute-HCV-II study. Hepatology. 2006;43: 250-256.

20. De Rosa FG, Bargiacchi O, Audagnotto S, et al. Twelve-week treatment of acute hepatitis $\mathrm{C}$ virus with PEGylated interferonalpha-2b in injection drug users. Clin Infect Dis. 2007;45:583588.

21. Fazili J, Mallonee S, Tierney WM, et al. Outcome of a hepatitis C outbreak among patients in a pain management clinic. Dig Dis Sci. 2010. doi:10.1007/s10620-010-1228-z.

22. Conjeevaram HS, Fried MW, Jeffers LJ, et al. Peginterferon and ribavirin treatment in African-American and Caucasian-American patients with hepatitis C genotype 1. Gastroenterology. 2006;131:470-477.

23. Barrett S, Goh J, Coughlan B, et al. The natural course of hepatitis $\mathrm{C}$ virus infection after 22 years in a unique homogenous cohort: spontaneous viral clearance and chronic HCV infection. Gut. 2001;49:423-430.

24. Kalantar-Zadeh K, Kilpatrick RD, McAllister CJ, et al. Hepatitis $\mathrm{C}$ virus and death risk in hemodialysis patients. J Am Soc Nephrol. 2007;18:1584-1593. 